\title{
INFLUENCE OF GATED PIPES IRRIGATION MANAGEMENT ON COTTON YIELD AND WATER EFFICIENCIES
}

\author{
Deshish ${ }^{1}$, E. E.; M. A. Metwally ${ }^{2}$ and S.A. Shaker ${ }^{1}$
}

ABSTRACT

Field experiments were conducted at the experimental farm of Sakha and Edko Agricultural Research Stations, Kafr El-Sheikh and Al-Behera Governorates (31 ${ }^{\circ} 05^{\prime} \mathrm{N}$ latitude and $30^{\circ} 56^{\prime}$ E longitude) during 2011 summer season to study the effect of different land leveling methods and orifice flow rates on cotton yield for Giza 86 variety and some water relations under furrow irrigation using gated pipes in the salt affected soils. The treatments were arranged in a split - plot design with four replicates. The main plots were assigned to four land leveling methods namely: laser land leveling with zero, 0.05 and $0.1 \%$ slopes in addition to traditional land leveling. Three orifice flow rates i. e. 1.5, 2.0 and 2.5 $l / s$ were allocated in the sub-plots. The main results in this study can be summarized as follows: -

1- The laser land leveling method achieved the highest average values of water productivity (70.1 $\mathrm{kg} \mathrm{m}^{-3}$ of water consumptive use), irrigation of water productivity $\left(62.2 \mathrm{~kg} \mathrm{~m}^{-3}\right.$ of water applied) and water application efficiency(95.2\%) of cotton crop with $0.1 \%$ slope compared with the conventional land leveling method which recorded the lowest average values of WP(40.2 $\mathrm{kg} \mathrm{m}^{-3}$ of water consumptive use), IWP(27.4 $\mathrm{kg} \mathrm{m}^{-3}$ of water applied) and Ea(70.2\%). This may be due to improvement of the soil moisture distribution in the root zone in case of the laser land leveling comparison with the conventional land leveling.

2- The data indicated that the highest amount of water applied $4112 \mathrm{~m}^{3}$ fed. $^{-1}$ )was recorded with the conventional land leveling method followed by laser land leveling at zero slope $\left(3365 \mathrm{~m}^{3} \mathrm{fed}^{-1}\right)$ while, the lowest amount of water applied $\left(2376 \mathrm{~m}^{3} \mathrm{fed} .^{-1}\right)$ was obtained the laser land leveling at $0.1 \%$ slope.

\footnotetext{
${ }^{1}$ Cotton Res. Inst., Agric. Res. Center, Giza, Egypt

${ }^{2}$ Agric. Eng. Res. Ins., Agric. Res. Center, Giza, Egypt.
} 
3- The furrow irrigation with gated pipes at $2.0 \mathrm{l} / \mathrm{s}$ orifice flow rate exhibited the highest average values of water productivity (60 and $59.5 \mathrm{~kg} \mathrm{~m}^{-3}$ of water consumptive use ), irrigation of water productivity (48 and $46.3 \mathrm{~kg} \mathrm{~m}^{-3}$ of water applied), water application efficiency (85.1 and $75.9 \%$ ) and seed cotton yield (1349 and $1432 \mathrm{~kg}$ fed. ${ }^{-1}$ ) compared with other orifice flow rates $(1.5$ and $2.5 \mathrm{l} / \mathrm{s})$. This may be due to increasing in soil moisture content in the root zone and also leashing and removing the soil salts.

4- The highest values of seed cotton yield ( $1515 \mathrm{and} 1609 \mathrm{~kg} \mathrm{fed}^{-1}$ ), number of opened bolls per plant (16.9and 18.6 bolls plant $^{-1}$, boll mass (3.95 and $3.62 \mathrm{~g}$ ), lint percentage ( 40.8 and $39.3 \%$ ), seed index ( 12.3 and $11.6 \mathrm{~g}$ ), 2.5 span length ( 34.5 and 32.7 ), fiber strength (42.8 and $41.5 \mathrm{~g} \mathrm{tex}^{-1}$ ) and plant height (115 and $105 \mathrm{~cm}$ ) were achieved with the laser land leveling method at $0.1 \%$ slope and furrow irrigation regime using gated pipes at orifice flow rate of $2 \mathrm{l} / \mathrm{s}$.

5- The interaction between land leveling and orifice flow rate of gated pipes had significant effect on seed cotton yield, its components and irrigation efficiencies under study. On the other hand, the highest values of seed cotton yield, seed index, boll mass, number of opened bolls and lint percentage were detected with the salt-affected soils(Edko region) because of increasing potassium and sodium cations ratio.

5- The laser land leveling at $0.1 \%$ slope and furrow irrigation using gated pipes at $2.0 \mathrm{l} / \mathrm{s}$ orifice flow rate is recommended for irrigating cotton because it is very suitable in case of the old lands and that have salinization problems to obtain highest irrigation efficiencies and cotton yields.

Keywords: Cotton, Gated pipes, Laser leveling, Orifice flow rate, water productivity.

\section{INTRODUCTION}

otton is the most important fiber crop used for making textile materials. It can be used in making a wide range of products, from diapers to explosives. It also still ranks as a major source of national income in Egypt. Cotton Productivity depends on a large number of environmental effects as well as crop and water management. An 
amount of irrigation water of 3400 and $4700 \mathrm{~m}^{3}$ fed. $^{-1}$ has been recommended by Ministry of Water Resources and Irrigation for lower and upper Egypt, respectively. On the other hand, Ministry of Agriculture in their publications (1961 up till now) devoted famers to schedule cotton irrigation to be every 15 and 10 days for lower and upper Egypt, respectively.

Water is the most limiting factor for plant production in arid and semiarid regions, and when the source of water is limited, the demand for water increases and water management will become an essential practice used by farmers. Surface irrigation is the oldest most used method of irrigation in Egypt. The gated pipe system usually has uniformly spaced orifices which can discharge equal amounts of water from each outlet as required by the plant per irrigation. Using the gated pipe system instead of ditches for conveying and distributing the irrigation water over the entire field may improve the surface irrigation, avoid weed problems, avoid loss of water by seepage and evaporation. There are many engineering factors affecting water distribution rates and uniformity of the gated pipe system as, pipe length and diameter, orifice spacing and diameter, pressure head and number of outlets operating simultaneously. The use of perforated pipes system is claimed to be one of the ways to improve the efficiency of the surface irrigation method( border and furrow ), (Morcos et al., 1994 ). Irrigation management consists of determining when to irrigate, and how much water to apply at each irrigation during each growth stage of plant and operation of irrigation system(Sharma et al., 1995). The irrigation application and distribution efficiencies were increased to 72.5 and $92 \%$ respectively by using gated pipes system through furrow irrigation,( Omara, 1997 ). The furrow stream size is usually between 0.2 and $3.0 \mathrm{~L} / \mathrm{s}$ and in more permeable soils, the maximum non-erosive flow should be used for wetting the end of the furrow as early as possible. The maximum slope is usually related to a non-erosive stream size. The land slope should generally be less than 3\% (Depeweg, 1998). The relationships between yield and water consumption were established and the preferred irrigation programs to be used with surface irrigation were developed(Tekinel et al., 1999). Osman (2000) mentioned that using gated pipes saved irrigation water by about of 12 and $29.24 \%$ for 
cotton and wheat, respectively. He also added that using gated pipes as an irrigation technique gave the highest yield of cotton and wheat comparing with traditional furrow irrigation system. Surface irrigation efficiency is maximum when systems are managed to minimize deep percolation and runoff while meeting irrigation requirements( Kanber et al., 2001). Mohammed (2002) found that the application efficiency of border irrigation increased as the outlet number of perforated pipe system increased. The obtained value ranged from 56.4 to $63.6 \%$. ElShahawy(2004) concluded that the highest value of actual water consumptive use $2900 \mathrm{~m}^{3}$ fed. $^{-1}$ was obtained from irrigation of all furrows under traditional land leveling in the first season. Meanwhile, the lowest value $2553.4 \mathrm{~m}^{3}$ fed. ${ }^{-1}$ was obtained from alternative furrow under precision land leveling in the second season. Traditional methods of land leveling are cumbersome, time consuming, and expensive, so more and more farmers are turning to modern methods to level the land. Laser leveling is a process of smoothing the land surface $(+2 \mathrm{~cm})$ from its average elevation using laser-equipped drag buckets. This technique is well known for achieving higher levels of accuracy in land leveling and offers great potential for water savings and higher grain yields( Jat et al., 2006). Effective land leveling increases yield, improves uniformity of crop maturity and reduces weeds and the amount of water needed for land preparation. Laser land leveling when applied under various crops has resulted in water savings up to $15-30 \%$ (Paca, 2009). The objective of the present study is to improve water management, irrigation efficiency and water use efficiency with gated pipe(GP) under salt affected soil conditions. Another objective of the present work is to study the effect of laser land leveling with different slopes and orifice flow rates of gated pipes irrigation system on cotton yield and some water relations under salt affected soil conditions.

\section{MATERIALS AND METHODS}

The field experiments were carried out in two sites at the experimental farm of Sakha and Edko Agricultural Research Stations, Kafr El-Sheikh and Al-Behera Governorates $\left(31^{\circ} 05^{\prime} \mathrm{N}\right.$ latitude and $30^{\circ} \quad 56^{\prime} \mathrm{E}$ longitude), Egypt during growing season of 2011 to study the effect of different land leveling methods and orifice flow rates on cotton yield for 
Giza 86 variety and water relations under surface irrigation system with gated pipes in the salts affected soil conditions.

Soil samples were randomly collected before and two days after each irrigation from 4 layers $(15 \mathrm{~cm}$ each) from the experimental sites and prepared for analysis of both physical and chemical properties at Sakha and Edko Agricultural Research Stations and presented in Tables (1and 2).

Table (1): Some physical and chemical properties of the Sakha experimental soil

\begin{tabular}{|c|c|c|c|c|c|c|c|c|c|}
\hline \multirow[t]{2}{*}{$\begin{array}{l}\text { Soil depth } \\
\text { (cm) }\end{array}$} & \multirow[t]{2}{*}{$\begin{array}{c}\text { Sand } \\
\%\end{array}$} & \multirow[t]{2}{*}{$\begin{array}{c}\text { Silt } \\
\%\end{array}$} & \multirow[t]{2}{*}{$\begin{array}{c}\text { Clay } \\
\%\end{array}$} & \multirow[t]{2}{*}{ Texture } & \multirow[t]{2}{*}{$\begin{array}{l}\mathrm{EC} \mathrm{dSm}^{-1} \\
\text { (Soil paste } \\
\text { extract) }\end{array}$} & \multirow[t]{2}{*}{$\begin{array}{c}\text { pH 1: } 2.5 \\
\text { Soil: Water } \\
\text { suspension }\end{array}$} & \multicolumn{3}{|c|}{$\begin{array}{c}\text { Available } \\
\text { nutrients } \\
\mathrm{Mg} \mathrm{kg}^{-1} \text { soil } \\
\end{array}$} \\
\hline & & & & & & & $\mathbf{N}$ & $\mathbf{P}$ & $\mathbf{K}$ \\
\hline $0-15$ & 33.0 & 28.6 & 38.4 & $n$ & 3. & 7.80 & & & \\
\hline $15-30$ & 33.4 & 28.4 & 38.2 & Clay & & 7.60 & & & \\
\hline $30-45$ & 33.2 & 28.5 & 38.3 & Clay loam & 3.4 & 7.70 & 22 & 1.6 & 18 \\
\hline $45-60$ & 33.0 & 28.6 & 38.4 & Clay loam & 3.49 & 7.75 & & & \\
\hline
\end{tabular}

Table (2): Some physical and chemical properties of the Edko experimental soil

\begin{tabular}{|c|c|c|c|c|c|c|c|c|c|}
\hline $\begin{array}{c}\text { Soil depth } \\
\text { (cm) }\end{array}$ & $\begin{array}{c}\text { Sand } \\
\mathbf{\%}\end{array}$ & $\begin{array}{c}\text { Silt } \\
\mathbf{\%}\end{array}$ & $\begin{array}{c}\text { Clay } \\
\mathbf{\%}\end{array}$ & Texture & $\begin{array}{c}\text { EC dSm } \mathbf{- 1} \\
\text { (Soil paste } \\
\text { extract) }\end{array}$ & $\begin{array}{c}\text { pH 1: 2.5 } \\
\text { Soil: Water } \\
\text { suspension }\end{array}$ & \multicolumn{2}{|c|}{$\begin{array}{c}\text { Available } \\
\text { nutrients } \\
\text { Mg kg-1 soil }\end{array}$} \\
\hline $0-15$ & 8.78 & 37.66 & 53.56 & clay & 4.30 & 8.30 & & & \\
$15-30$ & 9.33 & 37.43 & 53.24 & clay & 4.50 & 8.20 & & & \\
$30-45$ & 8.99 & 37.71 & 53.30 & clay & 4.60 & 8.15 & 18 & 1.2 & 16 \\
$45-60$ & 8.75 & 37.65 & 53.60 & clay & 4.90 & 8.10 & & & \\
\hline
\end{tabular}

Field capacity, permanent wilting point and bulk density were measured according to the standard methods outlined by Black (1983), Klute (1986) and Westerman (1990). Available soil moisture was calculated 
as the difference between the field capacity and permanent wilting point and presented in Tables ( 3 and 4 ).

Table (3): Average values of field capacity and bulk density of the Sakha experimental soil

\begin{tabular}{|c|c|c|c|c|c|c|}
\hline $\begin{array}{c}\text { Soil depth } \\
\text { cm }\end{array}$ & $\begin{array}{c}\text { Bulk density } \\
\left(\mathrm{kg} \mathrm{m}^{-3}\right)\end{array}$ & $\begin{array}{c}\text { Field } \\
\text { capacity } \\
\%\end{array}$ & $\begin{array}{c}\text { Per-wilting } \\
\text { point \% }\end{array}$ & $\begin{array}{c}\text { Available } \\
\text { water \% }\end{array}$ & $\begin{array}{c}\text { EC of } \\
\text { irrigation } \\
\text { water }\end{array}$ & $\begin{array}{c}\text { Readily available } \\
\text { water \% }\end{array}$ \\
\hline $0-15$ & 1120 & 40.50 & 20.64 & 19.86 & & 12.91 \\
$15-30$ & 1260 & 38.02 & 19.04 & 18.98 & 0.64 & 12.34 \\
$30-45$ & 1340 & 36.25 & 18.22 & 18.03 & $\mathrm{dSm}^{-1}$ & 11.72 \\
$45-60$ & 1380 & 35.75 & 17.91 & 17.84 & & 11.60 \\
\hline
\end{tabular}

Table (4): Average values of field capacity and bulk density of the

Edko experimental soil

\begin{tabular}{|c|c|c|c|c|c|c|}
\hline $\begin{array}{c}\text { Soil depth } \\
\mathrm{cm}\end{array}$ & $\begin{array}{c}\text { Bulk density } \\
\left(\mathrm{kg} \mathrm{m}^{-3}\right)\end{array}$ & $\begin{array}{c}\text { Field } \\
\text { capacity } \\
\%\end{array}$ & $\begin{array}{c}\text { Per-wilting point } \\
\%\end{array}$ & $\begin{array}{c}\text { Available } \\
\text { water } \%\end{array}$ & $\begin{array}{c}\text { EC of } \\
\text { irrigation } \\
\text { water }\end{array}$ & $\begin{array}{c}\text { Readily } \\
\text { available water } \\
\%\end{array}$ \\
\hline $0-15$ & 1340 & 41.90 & 21.63 & 20.27 & & 13.18 \\
$15-30$ & 1350 & 40.80 & 21.60 & 19.20 & 0.61 & 12.48 \\
$30-45$ & 1355 & 39.50 & 21.17 & 18.33 & $\mathrm{dSm}^{-1}$ & 11.91 \\
$45-60$ & 1360 & 39.10 & 20.95 & 18.15 & & 11.76 \\
\hline
\end{tabular}

\section{Experimental layout:}

The experimental design was laid out in split plot design with four replicates. Furrow irrigation using gated pipes with three orifice discharge rates i. e. 1.5, 2.0 and $2.51 / \mathrm{s}$ under average pressure heads ranging from 38 to $55 \mathrm{~cm}$ were the main treatments. The sub treatments were land leveling as follows:

a- Traditional land leveling a control treatment.

b- Laser land leveling with zero slope.

c- Laser land leveling with $0.05 \%$ slope.

d- Laser land leveling with $0.1 \%$ slope.

Agricultural tractor of $65 \mathrm{hp}$ and Laser leveling unit of width $4 \mathrm{~m}$ were used for leveling the experiment land. A $152 \mathrm{~mm}$ diameter and $6 \mathrm{~m}$ length aluminum pipes with gates, and orifice diameter $38 \mathrm{~mm}$ located at $75 \mathrm{~cm}$ spacing, were used to irrigate the grown plant through the furrow 
surface irrigation system. The system consisted of a diesel pump of flow rate $18 \mathrm{~m}^{3} \mathrm{~h}^{-1}$ which was operated by a diesel motor and connected by a venture meter, flow meter, discharge valve and gated pipes them having 8 orifices at $75 \mathrm{~cm}$ spacing. A pressure gage and pressure manometers were used to measure flow head from pumping unit and along the gated pipe. The pump draws water from canal into the gated pipes. The pipes were connected together using rubber ring jointing system. The last one of the gated pipes was equipped with gate cover at its end.

The two experimental sites were ploughed three times by using chisel plough on 5, 7 and $9^{\text {th }}$ April, 2011 seasons. The land was leveled by using traditional and laser leveling equipment on $13^{\text {th }}$ April. Egyptian cotton seeds, variety Giza 86 long staple were sown by the planter on $28^{\text {th }}$ April in hills spaced $25 \mathrm{~cm}$ apart. The land was ridged at $76 \mathrm{~cm}$ spacing and irrigated immediately after planting. A leaching irrigation was done on $9^{\text {th }}$ May. The hills were thinned to the desired stand before the second irrigation on $28^{\text {th }}$ May. The irrigation intervals were watering every $13^{\text {th }}$ days. Fertilizers were added as recommended in cotton production that is involved as basic dose of $200 \mathrm{~kg}$ fed. ${ }^{-1}$ Calcium super phosphate ( 15.5 $\% \mathrm{P}_{2} \mathrm{O}_{5}$ ) at land preparation besides $50 \mathrm{~kg}$ fed. ${ }^{-1}$ potassium sulphate ( 48 $\% \mathrm{k}_{2} \mathrm{O}$ ) before the fourth irrigation. Nitrogen fertilizer in the form of ammonium nitrate $33.5 \% \mathrm{~N}$ (60 kg fed. ${ }^{-1}$ ) was added in bands and divided in two equal portions, the first one was applied after thinning just before the second irrigation and the second part before the third irrigation. All other agricultural practices for cotton crop were done according to the common technical recommendations of Cotton Research Institute, except the factors under study. Cotton was sprayed with $50 \mathrm{~g}$ fed. ${ }^{-1}$ defoliant for dropping the cotton leaves on $2^{\text {nd }}$ October and the picking date was on $20^{\text {th }}$ October.

\section{1-Crop and Water parameters:}

\section{a- Amount of water applied:}

According to Awady, (1979) the discharge was measured by direct method using volume and time. This is one of the simplest and most accurate methods, the equation is

$$
\mathrm{Q}=\mathrm{vt}^{-1}
$$

\section{Where:}


Q : discharge $\left(. \mathrm{m}^{3} \mathrm{~h}^{-1}\right)$.

$\mathrm{V}:$ volume $\left(\mathrm{m}^{3}\right)$.

$\mathrm{H}$ : time (h).

\section{b-Water Consumptive Use (CU):}

Soil moisture content was determined before and after each irrigation to calculate water consumptive use according to the following equation (Hansen et al., 1979).

$$
\mathrm{SMD}=\mathrm{Cu}=\sum_{i=1}^{\mathrm{l}=4} \mathrm{D}_{1} \times \mathrm{D}_{\mathrm{b} 1} \times \frac{\mathrm{PW}_{2}-\mathrm{PW}_{1}}{100}
$$

\section{Where:}

SMD = Soil moisture depletion in the effective root zone, $\mathrm{cm}$.

$\mathrm{CU}=$ Water consumptive use, $\mathrm{cm}$.

$\mathrm{D}_{1} \quad=$ Soil layer depth, $\mathrm{cm}$ (root depth).

$\mathrm{D}_{\mathrm{b} 1}=$ Soil bulk density for this depth, $\mathrm{g} \mathrm{cm}^{-3}$.

$\mathrm{PW}_{1}=$ Soil moisture percentage before irrigation (\%, d.b.).

$\mathrm{PW}_{1}=$ Soil moisture percentage, 48 hours after irrigation $((\%$, d.b.).

I = Number of soil layers each $(15 \mathrm{~cm})$ depth.

\section{c- Water application efficiency (Ea):}

Application efficacy is the ratio of the average depth of irrigation water infiltrated and stored in the root zone to the average depth of irrigation applied. It was calculated for the $60 \mathrm{~cm}$ sol depth according to Michael (1978) and James (1988) as follows :

$$
\mathrm{Ea}=\frac{\mathrm{Ws}}{\mathrm{Wf}} \times 100
$$

\section{Where:}

$\mathrm{Ea}=$ Water application efficiency, \%.

$\mathrm{Ws}=$ Amount of water stored in the root zone, $\mathrm{m}^{3}$.

$\mathrm{Wf}=$ Amount of water added to each plot, $\mathrm{m}^{3}$.

\section{d-Water productivity (WP):}

Water productivity was calculated according to Ali et al. (2007) as follows: 


$$
\mathrm{WP}=\mathrm{Gy} \mathrm{ET}^{-1}
$$

Where:

fed. ${ }^{-1}$

Gy $=$ Seed cotton yield, $\mathrm{kg}$ fed. ${ }^{-1}$.

$\mathrm{ET}=$ Total water consumptive use of the growing season, $\mathrm{m}^{3}$

\section{e- Productivity of irrigation water (IWP):}

Productivity of irrigation water was calculated according to Ali et al. (2007) as follows:

$$
\mathrm{IWP}=\mathrm{Gy} \mathrm{IW}^{-1}
$$

\section{Where:}

$$
\begin{aligned}
& \text { Gy }=\text { Seed cotton yield }, \mathrm{kg} \text { fed. } .^{-1} \cdot \\
& \mathrm{IW}=\text { Irrigation water applied }, \mathrm{m}^{3} \text { fed. }{ }^{-1}
\end{aligned}
$$

\section{2- Cotton yield and its components:}

\section{a -Plant height:}

Cotton plant height was measured at the end of growing season. Samples of ten plants were chosen randomly from each treatment and were measured by a tape from the cotyledonary nodes to the top of the plant.

\section{b-No. of open and unopen bolls and boll mass:}

Samples of cotton bolls were taken randomly from each treatment to determine number of open bolls per plant and number of unopen bolls per plant. Boll mass was calculated as average value of ten bolls.

\section{c- Seed index:}

Seed index was calculated as the mass of 100 seeds in $\mathrm{g}$ which were taken randomly from each treatment

\section{d- Seed cotton yield:}

Seed cotton yield was calculated from picking all plants of the four inner rows of each treatment and transformed to $\mathrm{kg}$ fed. ${ }^{-1}$, the two outer rows of each treatment were picked separately to avoid any border effect.

\section{e- Lint percentage:}

Lint percentage was estimated as the ratio percentage between mass of lint cotton and mass of seed cotton. 


\section{f- Cotton fiber technological characters:}

Samples of lint were combined for the three replicates of each treatment and were sent to test fiber quality. The fiber length, strength and fineness were determined.

\section{3- Statistical analysis:}

The obtained data were statistically analyzed by analysis of variance. Combined analysis was done according to Gomez and Gomez (1984) .Means of the treatment were compared by the least significant difference (LSD) at 5\% level of significance as developed by Waller and Duncan (1969).

\section{RESULTS AND DISCUSSION}

\section{1- Seed cotton yield and its components : -}

Total seed cotton yield, number of opened and closed bolls per plant, boll weight, lint percentage, seed index, 2.5 span length, fiber strength and plant height under different methods of land leveling and different rates of orifice flow rate are presented in Tables 5 and 6 . The laser leveling method resulted in higher seed cotton yield comparing with the traditional leveling method for all irrigation treatments. The obtained values of seed cotton yield were 1018, 1237, 1415 and $1468 \mathrm{~kg}$ fed. ${ }^{-1}$ $\left(6.48,7.88,9.01\right.$ and 9.35 kantar fed $\left.^{-1}\right)$ for conventional, laser at zero, 0.05 and $0.1 \%$ land leveling methods respectively, with clay soil. They were 1079, 1310, 1523 and $1558 \mathrm{~kg} \mathrm{fed}^{-1}$ ( 6.87, 8.34, 9.7 and 9.92 kentar fed..$^{-1}$ ) with the soil affected by salts. It is clear that using the laser land leveling method at $0.1 \%$ slope increased the cotton yield by about 44.2 and $18.9 \%$ comparing with the traditional and laser at zero slope leveling methods, respectively. The seed cotton yield in the soil affected salts was more than that was obtained with the clay soil. These results may be due to increased ratio of sodium and potassium cations.

The presented data in Table 5 and 6 show also that the highest average values of seed cotton yield, number of opened and closed bolls per plant, boll weight, lint percentage, seed index, 2.5 span length, fiber strength and plant height were achieved with orifice flow rate of $21 / \mathrm{s}$ for all land leveling methods. The obtained average values of seed cotton 
yield were 1229,1349 and $1276 \mathrm{~kg} \mathrm{fed}^{-1}$ ( 7.83, 8.59 and $8.13 \mathrm{kentar}$ fed..$^{-1}$ ), achieved with orifice flow rates of $1.5,2.0$ and $2.51 / \mathrm{s}$, respectively. Generally, it is clear that, the laser land leveling method at $0.1 \%$ slope in addition to the furrow irrigation using gated pipes at $21 / \mathrm{s}$ orifice flow rate accomplished the maximum average values of seed cotton yield, number of opened and closed bolls per plant, boll weight, lint percentage, seed index, 2.5 span length, fiber strength and plant height .

\section{2- Water relations:}

\section{a- Irrigation water applied and water consumptive use :}

Amounts of irrigation water applied and water consumptive use $\left(\mathrm{m}^{3} \mathrm{fed}^{-}\right.$ ${ }^{1}$ ) as affected by method of land leveling and orifice flow rate of gated pipes regime are presented in Table 7. The average total amounts of irrigation water applied were 3729, 3099, 2678 and $2376 \mathrm{~m}^{3} \mathrm{fed}^{-1}$ with traditional, laser at zero, 0.05 and $0.1 \%$ land leveling, respectively for the clay soil, whereas, they were $4112,3365,3024$ and $2586 \mathrm{~m}^{3}$ fed. $^{-1}$ for the salt affected soils. It can be concluded that the lowest values of irrigation water were applied with the laser land leveling at $0.1 \%$ slope but, the highest average amounts of irrigation water were applied with the traditional land leveling for clay and salt affected soils. On the other hand, the average values of water consumptive use of cotton were significantly affected by land leveling method and orifice flow rate of furrow irrigation using gated pipes. It is clear that the minimum average values of CU (2095 and $2240 \mathrm{~m}^{3}$ fed. $^{-1}$ ) were obtained with the laser land leveling at $0.1 \%$ slope for clay and salt affected soils, respectively while, the maximum average values of CU (2535and $2676 \mathrm{~m}^{3} \mathrm{fed}^{-1}$ ) were recorded with the traditional land leveling in the clay and affected salted soils. These obtained results were in good agreement with those of El-Shahawy (2002) and Jat et al., (2006).

Data also indicated that the orifice flow rate of $2.5 \mathrm{l} / \mathrm{s}$ consumed the minimum amount of water applied $\left(2866 \mathrm{~m}^{3} \mathrm{fed}^{-1}\right)$ and water consumptive use $\left(2228 \mathrm{~m}^{3} \mathrm{fed}^{-1}\right)$ in the clay soil. Meanwhile, the maximum amount of water applied $\left(3411 \mathrm{~m}^{3} \mathrm{fed}^{-1}\right)$ and water consumptive use $\left(2485 \mathrm{~m}^{3}\right.$ fed..$\left.^{-1}\right)$ were recorded with the orifice flow rate 
of $1.5 \mathrm{l} / \mathrm{s}$ in the soils affected salts. These results indicated that, the amount of water applied and water consumptive use were related with land leveling methods and orifice flow rate of furrow irrigation using gated pipes. Generally, the soil affected salts consumed more amounts of irrigation applied and water consumptive use because of leaching irrigation and short irrigation intervals.

Table 5: Mean values of no. of open bolls/plant, no. of closed bolls/plant, boll weight, seed cotton yield and lint percentage as affected by land leveling techniques and orifice flow rate during 2011 growing season.

\begin{tabular}{|c|c|c|c|c|c|c|c|c|c|c|c|}
\hline \multirow{2}{*}{$\begin{array}{l}\text { Land leveling } \\
\text { techniques }\end{array}$} & \multirow{2}{*}{$\begin{array}{c}\text { Orifice } \\
\text { flow rate, } \\
\text { l/s. }\end{array}$} & \multicolumn{2}{|c|}{$\begin{array}{l}\text { No. of open } \\
\text { bolls/plant }\end{array}$} & \multicolumn{2}{|c|}{$\begin{array}{c}\text { No. of } \\
\text { closed } \\
\text { bolls/plant }\end{array}$} & \multicolumn{2}{|c|}{ Boll mass, $\mathbf{g}$} & \multicolumn{2}{|c|}{$\begin{array}{l}\text { Seed cotton } \\
\text { yield, kg } \\
\text { fed. }^{-1}\end{array}$} & \multicolumn{2}{|c|}{$\begin{array}{l}\text { Lint } \\
\text { percent., \% }\end{array}$} \\
\hline & & Saka & Edco & Saka & Edco & Saka & Edco & Saka & Edco & Saka & Edco \\
\hline \multirow{3}{*}{$\begin{array}{c}\text { Conventional } \\
\text { leveling }\end{array}$} & 1.5 & 12.4 & 14.0 & 5.8 & 5.2 & 2.83 & 2.65 & 950 & 1025 & 88.5 & 85.0 \\
\hline & 2.0 & 14.1 & 15.8 & 5.3 & 4.4 & 3.42 & 2.85 & 1090 & 1138 & 94.0 & 92.8 \\
\hline & 2.5 & 13.0 & 14.9 & 5.5 & 4.7 & 3.10 & 2.76 & 1015 & 1075 & 91.6 & 88.1 \\
\hline \multirow{3}{*}{$\begin{array}{l}\text { Laser leveling } \\
\text { at zero slope }\end{array}$} & 1.5 & 13.2 & 15.1 & 5.6 & 4.8 & 3.31 & 2.81 & 1185 & 1235 & 92.4 & 87.2 \\
\hline & 2.0 & 14.8 & 16.5 & 4.8 & 3.9 & 3.60 & 3.05 & 1296 & 1385 & 99.5 & 95.0 \\
\hline & 2.5 & 13.9 & 15.7 & 5.1 & 4.2 & 3.20 & 2.86 & 1230 & 1312 & 95.0 & 90.7 \\
\hline \multirow{3}{*}{$\begin{array}{l}\text { Laser leveling } \\
\text { at } 0.05 \% \text { slope }\end{array}$} & 1.5 & 14.0 & 15.9 & 4.5 & 3.7 & 3.24 & 2.95 & 1350 & 1465 & 98.6 & 93.4 \\
\hline & 2.0 & 15. & 17.3 & 3.9 & 2.9 & 3.71 & 3.35 & 1495 & 1596 & 105 & 100 \\
\hline & 2.5 & 14. & 16.4 & 4.2 & 3.3 & 3.35 & 3.18 & 1400 & 1508 & 102 & 95.3 \\
\hline \multirow{3}{*}{$\begin{array}{l}\text { Laser leveling } \\
\text { At } 0.1 \% \text { slope }\end{array}$} & 1.5 & 14.8 & 16.8 & 4.1 & 3.0 & 3.56 & 3.29 & 1430 & 1515 & 107 & 98.0 \\
\hline & 2.0 & 16.9 & 18.6 & 3.3 & 2.2 & 3.95 & 3.62 & 1515 & 1609 & 115 & 105 \\
\hline & 2.5 & 15.7 & 17.5 & 3.6 & 2.7 & 3.72 & 3.40 & 1460 & 1550 & 110 & 101 \\
\hline \multicolumn{2}{|c|}{ L.S.D at 0.05} & 0.06 & 0.07 & 0.01 & 0.02 & 0.03 & 0.05 & 28.4 & 23.6 & 2.13 & 2.05 \\
\hline \multirow{4}{*}{$\begin{array}{c}\text { Mean values } \\
\text { of } \\
\text { land leveling }\end{array}$} & Con. Lev. & 13.2 & 14.9 & 5.5 & 4.8 & 3.12 & 2.75 & 1018 & 1079 & 91.4 & 88.6 \\
\hline & $\begin{array}{l}\text { L. at } 0 \\
\text { slope } \\
\end{array}$ & 14.0 & 15.8 & 5.2 & 4.3 & 3.37 & 2.91 & 1237 & 1310 & 95.6 & 91.0 \\
\hline & L. at $.05 \%$ & 14.9 & 16.5 & 4.2 & 3.3 & 3.43 & 3.16 & 1415 & 1523 & 102 & 96.2 \\
\hline & L. at $0.1 \%$ & 15.8 & 17.6 & 3.7 & 2.6 & 3.74 & 3.44 & 1468 & 1558 & 111 & 101 \\
\hline \multicolumn{2}{|c|}{ L.S.D at 0.05} & 0.14 & 0.12 & 0.04 & 0.03 & 0.06 & 0.05 & 23.4 & 21.1 & 3.25 & 2.47 \\
\hline \multirow{3}{*}{$\begin{array}{c}\text { Mean values } \\
\text { of orifice } \\
\text { flow rate }\end{array}$} & 1.5 & 13.6 & 15.5 & 5.0 & 4.2 & 3.24 & 2.93 & 1229 & 1310 & 96.6 & 90.9 \\
\hline & 2.0 & 15.4 & 17.1 & 4.3 & 3.4 & 3.67 & 3.22 & 1349 & 1432 & 103 & 98.2 \\
\hline & 2.5 & 14.3 & 16.1 & 4.6 & 3.7 & 3.34 & 3.05 & 1276 & 1361 & 99.7 & 93.8 \\
\hline \multicolumn{2}{|c|}{ L.S.D at 0.05} & 0.26 & 0.24 & 0.06 & 0.04 & 0.05 & 0.03 & 26.9 & 31.4 & 4.11 & 3.28 \\
\hline
\end{tabular}


Table 6: Mean values of seed index, fiber strength 2.5 span strength, micronaire reeding and plant height as affected by land leveling techniques and orifice flow rate during 2011 growing season.

\begin{tabular}{|c|c|c|c|c|c|c|c|c|c|c|c|}
\hline \multirow{2}{*}{$\begin{array}{l}\text { Land leveling } \\
\text { techniques }\end{array}$} & \multirow{2}{*}{$\begin{array}{c}\text { Orifice flow } \\
\text { rate, } 1 / s .\end{array}$} & \multicolumn{2}{|c|}{$\begin{array}{c}\text { Seed } \\
\text { index,g }\end{array}$} & \multicolumn{2}{|c|}{$\begin{array}{l}2.5 \text { span } \\
\text { length }\end{array}$} & \multicolumn{2}{|c|}{$\begin{array}{c}\text { Fiber } \\
\text { streng., } \\
\text { g/tex }\end{array}$} & \multicolumn{2}{|c|}{$\begin{array}{l}\text { Micronaire } \\
\text { reeding. }\end{array}$} & \multicolumn{2}{|c|}{$\begin{array}{c}\text { Plant } \\
\text { height, } \mathrm{cm}\end{array}$} \\
\hline & & Saka & Edco & Saka & Edco & Saka & Edco & Saka & Edco & Saka & Edco \\
\hline \multirow{3}{*}{$\begin{array}{c}\text { Conventional } \\
\text { leveling }\end{array}$} & 1.5 & 10.3 & 9.5 & 32.8 & 31.2 & 41.1 & 39.8 & 3.6 & 4.0 & 35.8 & 34.5 \\
\hline & 2.0 & 11.2 & 10.2 & 33.4 & 31.7 & 41.8 & 40.5 & 4.2 & 4.5 & 37.3 & 36.1 \\
\hline & 2.5 & 10.6 & 9.8 & 33.1 & 31.5 & 41.5 & 40.1 & 3.8 & 4.2 & 36.6 & 35.2 \\
\hline \multirow{3}{*}{$\begin{array}{l}\text { Laser leveling } \\
\text { at zero slope }\end{array}$} & 1.5 & 10.9 & 10.2 & 33.1 & 31.4 & 41.3 & 40.3 & 3.9 & 4.6 & 37.5 & 36.4 \\
\hline & 2.0 & 11.6 & 10.8 & 33.8 & 32.1 & 42.1 & 40.8 & 4.4 & 4.9 & 39.3 & 37.5 \\
\hline & 2.5 & 11.3 & 10.4 & 33.5 & 31.6 & 41.7 & 40.5 & 4.1 & 4.6 & 38.7 & 37.1 \\
\hline \multirow{3}{*}{$\begin{array}{l}\text { Laser leveling } \\
\text { at } 0.05 \% \text { slope }\end{array}$} & 1.5 & 11.4 & 10.6 & 33.7 & 31.8 & 41.9 & 40.6 & 4.2 & 4.9 & 38.2 & 37.6 \\
\hline & 2.0 & 12.1 & 11.3 & 34.2 & 32.3 & 42.4 & 41.1 & 4.6 & 5.3 & 39.4 & 38.3 \\
\hline & 2.5 & 11.7 & 10.9 & 33.9 & 32.0 & 42.1 & 40.9 & 4.3 & 5.1 & 38.6 & 37.9 \\
\hline \multirow{3}{*}{$\begin{array}{l}\text { Laser leveling } \\
\text { At } 0.1 \% \text { slope }\end{array}$} & 1.5 & 11.9 & 11.1 & 34.1 & 32.2 & 42.5 & 41.0 & 4.5 & 5.2 & 39.5 & 38.5 \\
\hline & 2.0 & 12.3 & 11.6 & 34.5 & 32.7 & 42.8 & 41.5 & 4.8 & 5.6 & 40.8 & 39.3 \\
\hline & 2.5 & 12.1 & 11.3 & 34.3 & 32.4 & 42.6 & 41.2 & 4.6 & 5.4 & 40.2 & 38.8 \\
\hline \multicolumn{2}{|c|}{ L.S.D at 0.05} & 0.13 & 0.11 & 0.09 & 0.07 & 0.06 & 0.05 & 0.03 & 0.04 & 0.22 & 0.31 \\
\hline \multirow{3}{*}{$\begin{array}{c}\text { Mean values } \\
\text { of } \\
\text { land leveling }\end{array}$} & Con. Lev. & 10.7 & 9.8 & 33.1 & 31.5 & 41.5 & 40.1 & 3.9 & 4.2 & 36.6 & 35.3 \\
\hline & L. at 0 slope & 11.3 & 10.5 & 33.5 & 31.7 & 41.7 & 40.5 & 4.1 & 4.7 & 38.5 & 37.0 \\
\hline & L. at $0.1 \%$ & 12.1 & 11.3 & 34.3 & 32.4 & 42.6 & 41.2 & 4.6 & 5.4 & 40.2 & 38.9 \\
\hline \multicolumn{2}{|c|}{ L.S.D at 0.05} & 0.16 & 0.21 & 0.32 & 0.26 & 0.19 & 0.12 & 0.09 & 0.11 & 0.14 & 0.24 \\
\hline & L. at $0.1 \%$ & 12.1 & 11.3 & 34.3 & 32.4 & 42.6 & 41.2 & 4.6 & 5.4 & 40.2 & 38.9 \\
\hline \multirow{3}{*}{$\begin{array}{c}\text { Mean values } \\
\text { of orifice } \\
\text { flow rate }\end{array}$} & 1.5 & 11.1 & 10.4 & 33.4 & 31.7 & 41.7 & 40.4 & 4.1 & 4.7 & 37.8 & 36.8 \\
\hline & 2.0 & 11.8 & 11.0 & 34.0 & 32.2 & 42.3 & 41.0 & 4.5 & 5.1 & 39.2 & 37.8 \\
\hline & 2.5 & 11.4 & 10.6 & 33.7 & 31.9 & 42.0 & 40.7 & 4.2 & 4.8 & 38.5 & 37.3 \\
\hline \multicolumn{2}{|c|}{ L.S.D at 0.05} & 0.09 & 0.14 & 0.12 & 0.13 & 0.21 & 0.17 & 0.12 & 0.09 & 0.31 & 0.26 \\
\hline
\end{tabular}

\section{b- Water application efficiency:}

Using the gated pipes in irrigating cotton crop increased the water application efficiency compared with traditional furrow irrigation because of less irrigation water, decreased loss irrigation water in root zone and gave highest value of production. Values of water application efficiency were affected by land leveling method and orifice flow rate of gated pipes under furrow irrigation as presented in Table 8 . The water 
application efficiency increased by $27.4 \%$ as a result of using laser leveling instead of traditional leveling, but it increased by $16.1 \%$ by increasing the slope from zero to $0.1 \%$ during the laser land leveling. The average values of water application efficiency were 74.3, 75.9 and 78.8\% with orifice flow rates of $1.5,2.0$ and $2.5 \mathrm{l} / \mathrm{s}$, respectively for the soil affected by salts. The highest values of water application efficiency were recorded with the orifice flow rate of $2.5 \mathrm{l} / \mathrm{s}$ for all land leveling methods. The water application efficiency of the clay soil was more than obtained with the soil affected by salts.

\section{c- Water productivity (WP):}

Water productivity (WP) expressed in $\mathrm{kg}$ of seed cotton yield $\mathrm{m}^{-3}$ of water consumed and productivity of irrigation water (IWP) in $\mathrm{kg}$ of seed cotton yield $\mathrm{m}^{-3}$ of irrigation water applied as affected by land leveling method and orifice flow rate are presented in Table 8 . Water productivity determines the capacity of the plants to convert the consumed water to yield. The obtained results show that the laser leveling method at $0.1 \%$ slope gave the highest average values of WP $\left(70.1\right.$ and $69.7 \mathrm{~kg} \mathrm{~m}^{-3}$ water consumed), while the lowest average of WP (40.2 and $40.4 \mathrm{~kg} \mathrm{~m}^{-3}$ water consumed) were recorded with the traditional leveling method for the clay and salt affected soils, respectively. The WP values increased by 31 $\%$ when the slope of laser land leveling was increased from zero to $0.1 \%$, while it increased by $56.7 \%$ when the laser leveling was used instead of traditional leveling.

The results also indicated that the obtained average values of WP were $53.8,60.0$ and $58.2 \mathrm{~kg} \mathrm{~m}^{-3}$ water consumed with orifice flow rate of 1.0, 2.0 and $2.5 \mathrm{l} / \mathrm{s}$, respectively. The orifice flow rate of $2.0 \mathrm{l} / \mathrm{s}$ gave the maximum average values of water productivity compared with the other flow rates 1.5 and $2.5 \mathrm{l} / \mathrm{s}$. 
Table 7: Mean values of water applied, water consumption use and stored water as affected by land leveling techniques and orifice flow rate during 2011 growing season.

\begin{tabular}{|c|c|c|c|c|c|c|c|}
\hline \multirow[t]{2}{*}{$\begin{array}{l}\text { Land leveling } \\
\text { techniques }\end{array}$} & \multirow{2}{*}{$\begin{array}{c}\text { Orifice } \\
\text { flow rate, } \\
\text { l/s. }\end{array}$} & \multicolumn{2}{|c|}{$\begin{array}{l}\text { Water } \\
\text { applied, } \\
\text { m }^{3} \text { fed }^{-1}\end{array}$} & \multicolumn{2}{|c|}{$\begin{array}{c}\text { Water } \\
\text { consumptive use, } \\
\text { m }^{3} \text { fed }^{-1} \mathbf{w}\end{array}$} & \multicolumn{2}{|c|}{$\begin{array}{l}\text { Stored water, } \\
\text { m }^{3} \text { fed }^{-1}\end{array}$} \\
\hline & & Sakha & Edco & Sakha & Edco & Sakha & Edco \\
\hline \multirow{3}{*}{$\begin{array}{c}\text { Conventional } \\
\text { leveling }\end{array}$} & 1.5 & 3860 & 4250 & 2582 & 2710 & 2655 & 2622 \\
\hline & 2.0 & 3722 & 4105 & 2530 & 2668 & 2610 & 2580 \\
\hline & 2.5 & 3605 & 3980 & 2493 & 2650 & 2582 & 2554 \\
\hline \multirow{3}{*}{$\begin{array}{l}\text { Laser leveling } \\
\text { at zero slope }\end{array}$} & 1.5 & 3213 & 3524 & 2350 & 2535 & 2583 & 2510 \\
\hline & 2.0 & 3105 & 3360 & 2300 & 2490 & 2550 & 2485 \\
\hline & 2.5 & 2980 & 3210 & 2280 & 2484 & 2486 & 2435 \\
\hline \multirow{3}{*}{$\begin{array}{l}\text { Laser leveling } \\
\text { at } 0.05 \% \text { slope }\end{array}$} & 1.5 & 2791 & 3150 & 2225 & 2420 & 2500 & 2470 \\
\hline & 2.0 & 2660 & 3025 & 2190 & 2343 & 2461 & 2425 \\
\hline & 2.5 & 2584 & 2896 & 2085 & 2299 & 2410 & 2365 \\
\hline \multirow{3}{*}{$\begin{array}{l}\text { Laser leveling } \\
\text { at } 0.1 \% \text { slope }\end{array}$} & 1.5 & 2466 & 2720 & 2131 & 2275 & 2355 & 2326 \\
\hline & 2.0 & 2366 & 2555 & 2100 & 2260 & 2267 & 2220 \\
\hline & 2.5 & 2295 & 2490 & 2054 & 2185 & 2180 & 2193 \\
\hline \multicolumn{2}{|c|}{ L.S.D at 0.05} & 56.12 & $\begin{array}{c}63.0 \\
5 \\
\end{array}$ & 13.25 & 1134 & 21.32 & 19.85 \\
\hline & Con. Lev. & 3729 & 4112 & 2535 & 2676 & 2616 & 2585 \\
\hline & $\begin{array}{c}\text { L. at 0 } \\
\text { slope }\end{array}$ & 3099 & 3365 & 2310 & 2503 & 2540 & 2477 \\
\hline & L. at $.05 \%$ & 2678 & 3024 & 2167 & 2354 & 2457 & 2420 \\
\hline & L. at $0.1 \%$ & 2376 & 2588 & 2095 & 2240 & 2267 & 2246 \\
\hline \multicolumn{2}{|c|}{ L.S.D at 0.05} & 225.6 & $\begin{array}{c}263 . \\
7\end{array}$ & 75.41 & 116.4 & 63.50 & 51.32 \\
\hline \multirow{3}{*}{$\begin{array}{c}\text { Mean values } \\
\text { of orifice } \\
\text { flow rate }\end{array}$} & 1.5 & 3083 & 3411 & 2322 & 2485 & 2523 & 2482 \\
\hline & 2.0 & 2963 & 3261 & 2280 & 2440 & 2472 & 2428 \\
\hline & 2.5 & 2866 & 3144 & 2228 & 2404 & 2415 & 2387 \\
\hline \multicolumn{2}{|c|}{ L.S.D at 0.05} & 81.23 & $\begin{array}{c}112 . \\
4\end{array}$ & 45.16 & 33.71 & 32.24 & 29.85 \\
\hline
\end{tabular}

\section{d- Productivity of irrigation water (IWP):}

Results presented in Table 8 indicate that the highest average values of IWP (62.2 and 60. $\mathrm{kg}$ seed cotton $\mathrm{m}^{-3}$ of irrigation water applied) were obtained with using the laser land leveling method at $0.1 \%$ slope while, the lowest ones ( 27.4 and $26.3 \mathrm{~kg} \mathrm{~m}^{-3}$ of irrigation water applied ) were 
obtained from the soil which was leveled by using the traditional leveling method for the clay and affected salts soils, respectively. These results could be attributed to the significant differences among seed cotton yield, evapotranspiration and water applied values.

Concerning the effect of orifice flow rate on the PIW, as shown in Table 8 results reveal that irrigating cotton crop using furrow irrigation by gated pipes at $2.01 / \mathrm{s}$ orifice flow rate accomplished the maximum average values of PIW (48 and $46.3 \mathrm{~kg} \mathrm{~m}^{-3}$ of irrigation water applied), whereas the minimum average values of PIW (42 and $40.4 \mathrm{~kg} \mathrm{~m}^{-3}$ of irrigation water applied) were obtained with irrigation $1.5 \mathrm{l} / \mathrm{s}$ orifice flow rate in the clay and affected salts soils, respectively.

Table 8: Mean values of water applied efficiency, water productivity (WP) and irrigation of water productivity (IPW) as affected by land leveling techniques and orifice flow rate during 2011 growing season.

\begin{tabular}{|c|c|c|c|c|c|c|c|}
\hline \multirow{2}{*}{$\begin{array}{l}\text { Land leveling } \\
\text { techniques }\end{array}$} & \multirow{2}{*}{$\begin{array}{c}\text { Orifice flow } \\
\text { rate, } 1 / \mathbf{s} .\end{array}$} & \multicolumn{2}{|c|}{$\begin{array}{l}\text { Water application } \\
\text { efficiency, } \%\end{array}$} & \multicolumn{2}{|c|}{$\mathrm{WP}, \mathrm{kg} \mathrm{m}^{-3}$} & \multicolumn{2}{|c|}{ IWP, $\mathrm{kg} \mathrm{m}^{-3}$} \\
\hline & & Sakha & Edco & Sakha & Edco & Sakha & Edco \\
\hline \multirow{3}{*}{$\begin{array}{l}\text { Conventional } \\
\text { leveling }\end{array}$} & 1.5 & 68.8 & 61.7 & 36.8 & 37.8 & 24.6 & 24.1 \\
\hline & 2.0 & 70.1 & 62.9 & 43.1 & 42.7 & 29.3 & 27.7 \\
\hline & 2.5 & 71.6 & 64.2 & 40.7 & 40.6 & 28.2 & 27.0 \\
\hline \multirow{3}{*}{$\begin{array}{l}\text { Laser leveling } \\
\text { at zero slope }\end{array}$} & 1.5 & 80.4 & 71.2 & 50.4 & 48.7 & 36.9 & 35.1 \\
\hline & 2.0 & 82.1 & 74.2 & 56.3 & 55.6 & 41.7 & 41.2 \\
\hline & 2.5 & 83.4 & 76.5 & 53.9 & 52.8 & 41.3 & 40.9 \\
\hline \multirow{3}{*}{$\begin{array}{l}\text { Laser leveling } \\
\text { at } 0.05 \% \text { slope }\end{array}$} & 1.5 & 89.6 & 78.4 & 60.7 & 60.5 & 48.4 & 46.5 \\
\hline & 2.0 & 92.5 & 80.2 & 68.3 & 68.1 & 56.2 & 52.8 \\
\hline & 2.5 & 93.3 & 85.1 & 67.1 & 65.6 & 54.2 & 52.4 \\
\hline \multirow{3}{*}{$\begin{array}{l}\text { Laser leveling } \\
\text { At } 0.1 \% \text { slope }\end{array}$} & 1.5 & 94.7 & 85.8 & 67.1 & 66.6 & 58.0 & 55.7 \\
\hline & 2.0 & 95.8 & 86.2 & 72.1 & 71.6 & 64.9 & 63.4 \\
\hline & 2.5 & 95.0 & 89.5 & 71.1 & 70.9 & 63.6 & 62.2 \\
\hline \multicolumn{2}{|c|}{ L.S.D at 0.05} & 0.062 & 0.125 & 0.043 & 0.234 & 0.118 & 0.109 \\
\hline \multirow{4}{*}{$\begin{array}{c}\text { Mean values } \\
\text { of } \\
\text { land leveling }\end{array}$} & Con. Lev. & 70.2 & 62.9 & 40.2 & 40.4 & 27.4 & 26.3 \\
\hline & L. at 0 slope & 82.0 & 74.0 & 53.5 & 52.4 & 40.0 & 39.1 \\
\hline & L. at .05\% & 91.2 & 81.2 & 65.4 & 64.7 & 52.9 & 50.6 \\
\hline & L. at $0.1 \%$ & 95.2 & 87.2 & 70.1 & 69.7 & 62.2 & 60.4 \\
\hline \multicolumn{2}{|c|}{ L.S.D at 0.05} & 3.15 & 4.63 & 4.68 & 3.91 & 8.36 & 7.82 \\
\hline \multirow{3}{*}{$\begin{array}{c}\text { Mean values } \\
\text { of orifice } \\
\text { flow rate }\end{array}$} & 1.5 & 83.4 & 74.3 & 53.8 & 53.4 & 42.0 & 40.4 \\
\hline & 2.0 & 85.1 & 75.9 & 60.0 & 59.5 & 48.0 & 46.3 \\
\hline & 2.5 & 85.8 & 78.8 & 58.2 & 57.5 & 46.8 & 45.6 \\
\hline \multicolumn{2}{|c|}{ L.S.D at 0.05} & 0.57 & 0.89 & 1.34 & 1.82 & 0.95 & 0.79 \\
\hline
\end{tabular}




\section{CONCLUSION}

It is recommended to level the soil using the laser land leveling at $0.1 \%$ slope and $\mathrm{f}$ irrigate cotton crop using the furrow irrigation by gated pipes at $2.0 \mathrm{l} / \mathrm{s}$ orifice flow rate because it is very suitable in case of the clay and salt affected soils. to obtain the highest values of seed cotton yield, water productivity (WP), irrigation of water productivity (IWP), water application efficiency(Ea), number of opened bolls per plant, boll mass, lint percentage, seed index, 2.5 span length, fiber strength and plant height.

\section{REFERENCES}

Ali, M. H.; M. R. Hoque; A. A. Hassan and A. Khair (2007). Effects of deficit irrigation on yield, water productivity, and economic returns of wheat. Agricultural Water Management 92 (3): 151-161.

Awady, M.N.(1979). Irrigation and drainage engineering, Col. Ag.,A.Shams U., Textbook in Arabic :112p.

Black, C.A. (1983). "Methods of soil analysis" Part I and II. Amer. Agron. Inc. Publ., Madison, Wisc., USA.

Depeweg, H. (1998). Field irrigation and drainage, Surface irrigation methods, Lecture Notes, International, Hydraulic and Environmental Engineering (IHE ). Delft, The Netherlands.

El-Shahawy, M. I. (2004). Some aspects of water management in furrow irrigation under cotton crop. J. Agric. Sci. Mansoura Univ., 29(6): 3651-3660.

Gomez, K.A and A. Gomez (1984). Statistical procedures for agricultural research. $1^{\text {st }}$ ed. John Wiley Sons, N.Y.

Hansen, U. W.; O. W. Israelsen and Q. E. Stringharm (1979). Irrigation Principles and Practices. 4th (ed.). John Willey and Sons., Inc. New York.

James, L. G. (1988). Principles of farm irrigation system design. John Willey and Sons., Inc. New York, USA. PP:543.

Jat, M. L. ; Parvesh Chandna ; Raj Gupta ; S. K. Sharma and M. A. Gill (2006). Laser Land Leveling: A Precursor Technology for 
Resource Conservation. Rice-Wheat Consortium Technical Bulletin Series 7. New Delhi: Rice-Wheat Consortium for the IndoGangetic Plains.

Kanber, R. ; H. Koksal ; S. Onder ; S. Kapur and S. Sahan (2001). Comparison of surge and continuous furrow methods for cotton in the Harran plain. Agric. Water Manage 47: 119-135.

Klute, A. (1986). Methods of soil analysis. Part 1.2nd ed. ASA and sssA. Madison. John Willey and Sons., Inc. N. Y.

Michael, A.M. (1978). Irrigation theory and practice, Vikas publishing house PVTLTD New Delhi, Bombay.

Mohammed, A. S. H. (2002). A study of water distribution efficiency by perforated pipes for border irrigation system. MSc. Thesis, Agric. Eng. Dept. Fac. of Ag. Minufiya Univ., Egypt.

Morcos, M. A., A. F. El- Sahrigi, M. Hanafy and S. S. Hassan (1994). A

Omara, A. I. (1997). Implementation and evaluation of gated pipe for furrow irrigation system. M. SC. Th. Agric. Eng. Dept. Alex. Univ.

Osman, H. E. (2000). Gated pipes techniques for improved surface irrigation. 8 Conf. AG. Dev. Res. Ag., Ain Shams Univ. Cairo, Nov. 20- 22:. 145- 155.

PACA (2009). 1 st Floor, NASC Complex, DPS Marg, Pusa, New Delhi- 110012 INDIA. Website: www.conserveagri.org

Sharma, S. N.; R. Prasad and S. Singh(1995). New multiple cropping systems for higher production profit. Indian J. of Agric. Sci. 65,4: 237-241.

Tekinel, O. ; R. Kanber and H. Koksal (1999). Irrigation of cotton: Turkish experience. In: proc. 1st symp. on cotton Ag. fiber Tech.and Textile in Turkish world Kahramanmar as Turkey.

Waller, R.A. and D.B. Duncan. (1969). Symmetric multiple comparison problem Amer. Stat. Assoc. Jour. Dec., 1485-1503.Zagazig J. Agric. Res., 19: 595-606. 
Weaterman, R.L.E. (1990). Soil testing and plant analysis. Thirded. Soil sc. Soc. of Am. Inc. Madison, Wisc, USA

\section{الملخص العربيى}

تأثير إدارة الري بالأنابيب المبوبة علي إنتاجية محصول القطن وكفاعات الري

محمد علي متولي '، الاسوقي الاسوقي دشيش † وشاكر محمد شاكر'

أجري هذا البحث بالمزرعة البحثية بمحطتي البحوث الزر اعية بسخا و إدكو - بمحافظتي كفر

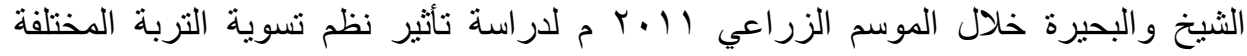

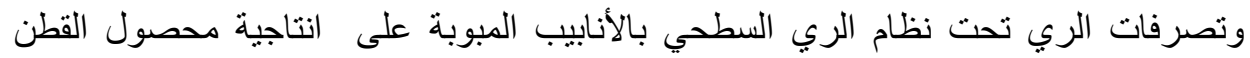

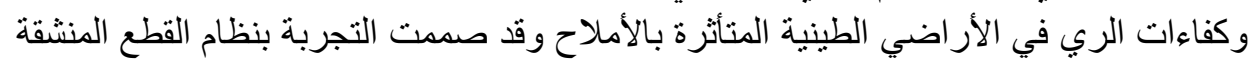

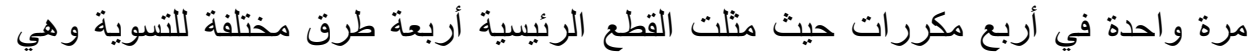

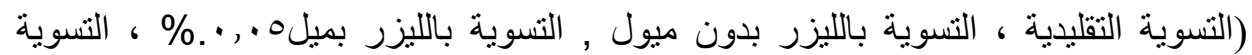

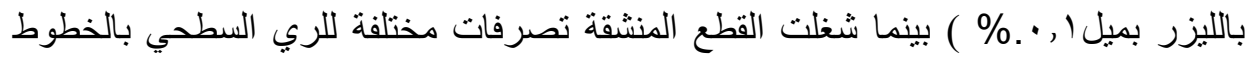

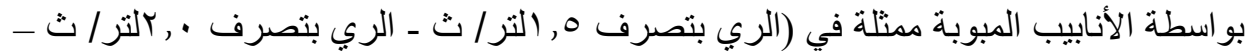

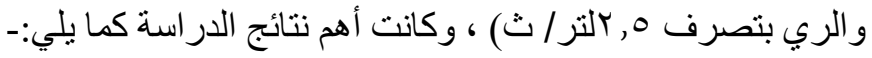

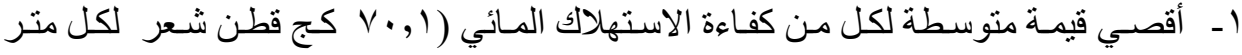

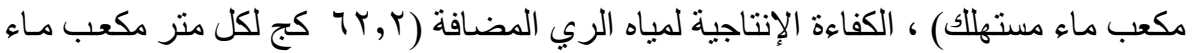

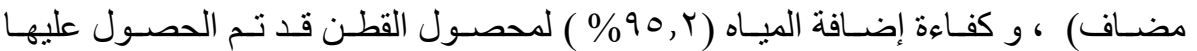
باستخدام طريقة التسوية بالليزر بميل ا , •\% بالمقارنة بطريقة التسوية التقليدية التي سجلت

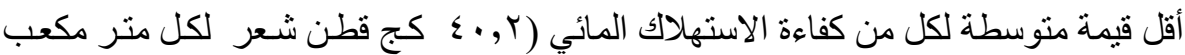

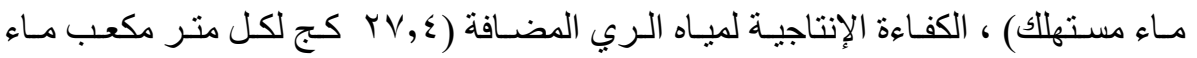

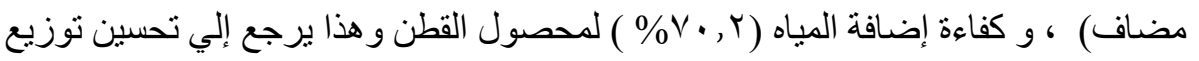

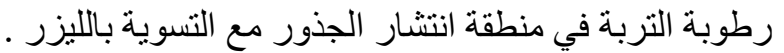

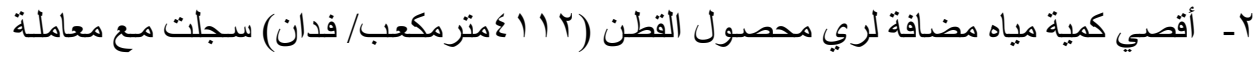

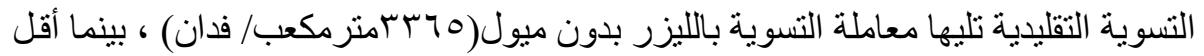

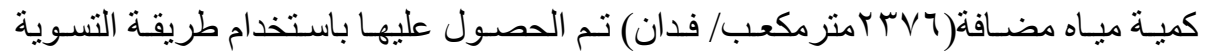

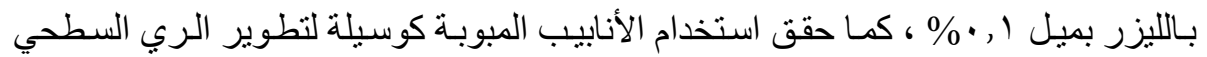

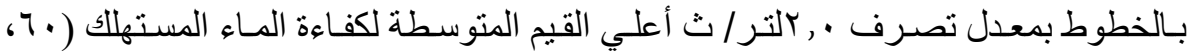

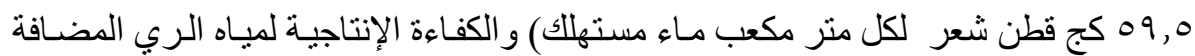

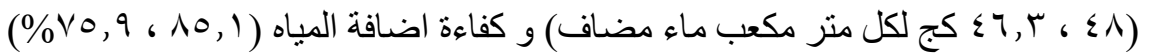

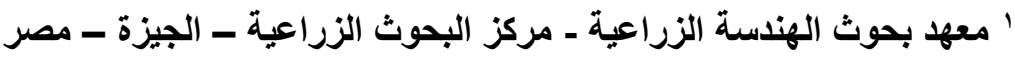

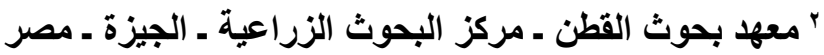




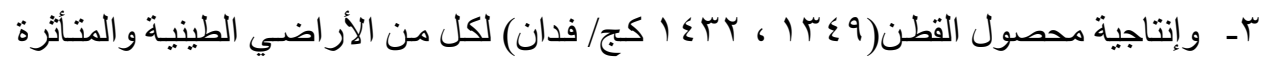

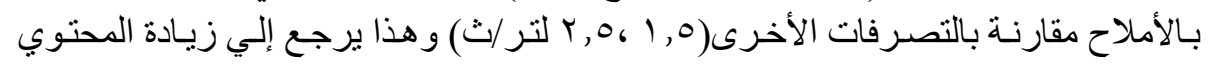

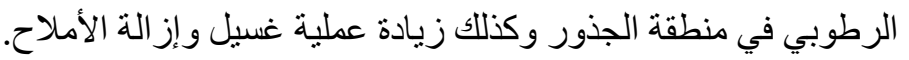

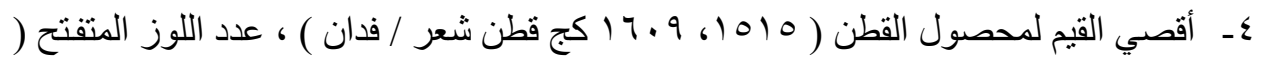

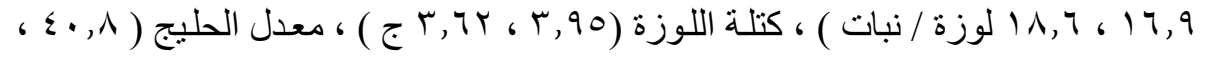
(

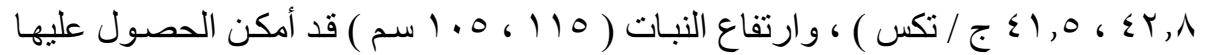

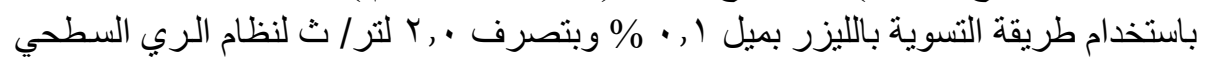
بالخطوط باستخدام الأنابيب المبوبة.

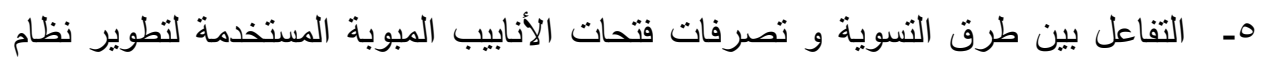

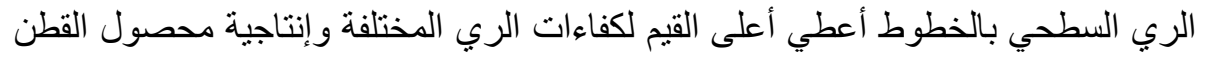

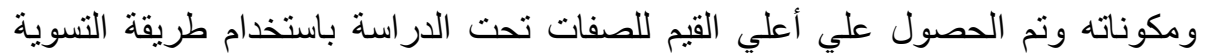

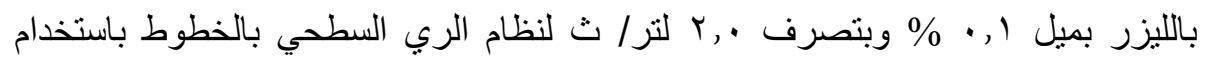

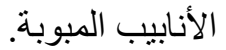

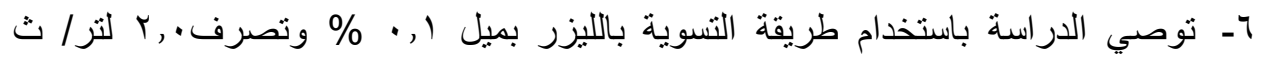

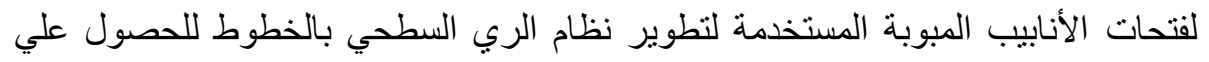
أعلي إنتاجية لمحصول القطن و أقصي كفاءة للري. 